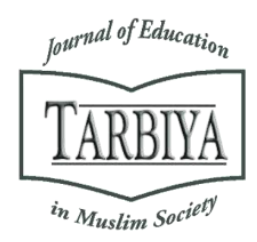

Available online at TARBIYA: Journal of Education in Muslim Society Website:

http://journal.uinjkt.ac.id/index.php/tarbiya

TARBIYA: Journal of Education in Muslim Society, 5(1), 2018, 30-42

\title{
THE SYNERGY OF ARTS, NEUROSCIENCE, AND ISLAM IN EARLY CHILDHOOD LEARNING IN YOGYAKARTA
}

\author{
Suyadi \\ Ahmad Dahlan University Yogyakarta, Indonesia \\ E-mail: suyadi@fai.uad.ac.id
}

Received: $18^{\text {th }}$ March 2018; Revised: $14^{\text {th }}$ April 2018; Accepted: $27^{\text {th }}$ June 2018

\section{Abstract}

Arts in Islam is an expression of tawheed (oneness of God) and prophetic, which is in neuroscience stated as able to activate the brain, affect emotions, and improve social skills, motivation, cultural awareness, and aesthetic appreciation. The purpose of this research is to analyze the synergy of arts and science in early childhood learning at three Early Childhood Education institutions in Yogyakarta, which has a variety of Islamic styles. The approach of this research was qualitative descriptive. Data collection techniques were conducted by observation, in-depth interviews, and documentation. The data analysis technique was done in descriptive, interpretative, and comparative with reference to neuroscience learning theory. The results showed that what makes art always controversial with the Islamic teachings is not in essence, but on other things that are often expressed unethically. Arts in Islamic education of early childhood are the religious arts that empathic and full-meaning, thus not only in accordance with Islamic teachings but becomes the basic needs of every people. The synergy of arts and science in early childhood learning can improve learning creativity.

Keywords: arts, Islamic education; neuroscience; early childhood learning

\section{Abstrak}

Seni dalam Islam merupakan ekspresi tauhid dan profetik, yang dalam neurosains dinyatakan mampu mengaktivasi otak, mempengaruhi emosi, meningkatkan keterampilan sosial, motivasi, kesadaran budaya dan apresiasi estetika. Tujuan penelitian ini adalah menganalisis sinergi seni dan sains dalam pembelajaran anak usia dini pada tiga lembaga PIAUD di Yogyakarta yang memiliki corak keisalaman beragam. Pendekatan penelitian ini adalah kualitatif deskriptif. Teknik pengumpulan data dilakukan dengan observasi, wawancara mendalam dan dokumentasi. Teknik anailis data dilakukan secara deskriptif, interpretatif dan komparatif dengan mengacu teori pembelajaran neurosains. Hasil penelitian menunjukkan bahwa yang menjadikan seni selalu kontroversi dengan ajaran Islam bukan pada esensinya, melainkan pada hal-hal lain yang sering kali diekspresikan secara tidak etis. Seni dalam pendidikan Islam anak usia dini adalah seni religi yang empatik dan meaning fullness sehingga tidak saja sesuai dengan ajaran Islam melainkan menjadi kebutuhan asasi setiap orang. Sinergi seni dan sains dalam pembelajaran anak usia dini dapat meningkatkan kreatifitas belajar.

Kata kunci: seni; pendidikan Islam; neurosains; pembelajaran anak usia dini

How to Cite : Suyadi. (2018). The Synergy of Arts, Neuroscience, and Islam in Early Childhood Learning in Yogyakarta. TARBIYA: Journal of Education in Muslim Society, 5(1), 30-42. doi:10.15408/tjems.v5i1.7934.

Permalink/DOI: http://dx.doi.org/10.15408/tjems.v5i1.7934

TARBIYA: Journal of Education in Muslim Society, P-ISSN: 2356-1416, e-ISSN: 2442-9848

This is an open access article under CC-BY-SA license (https://creativecommons.org/licenses/by-sa/4.0/) 


\section{Introduction}

All this time, arts and science are considered enemy (David A. Sousa, 2012), it is considered not in line with the Islamic shari'ah (law) (Suhendra, 2017). Arts are considered subjective, imaginative, narrative, and often controversial while science is considered logical, critical, objective, and factual (Donald Olding Hebb, 2012), while religion is regarded as intuitive and spiritual (Pasiak, 2016) and even the supernatural unreachable by mind (Mawardi, 2013). In neuroscience, arts is considered the work of the right brain while science is considered the work of the left brain, while religion is considered as a result of intuitive brain work (Taufiq Pasiak, 2008). This creates the impression that artists, scientists, and religionist think with separate parts of the brain. In fact, the classic saying that religion makes life more focused, science makes life easier, and arts makes life more beautiful. Separating between arts, science and religion will have an impact on split personality. Conversely, synergizing arts, science, and Islam will form a holistic personality; fun or beautiful, smart, and noble.

For decades, there are many scientists contradict arts and Islam. Kurdian compares the hadiths which on one hand prohibit arts (HR. Al-Bukhari no. 3896, CD Mausyu'ah), but on the other hand allows arts (Hadith Musnad Ahmad no. 4535 and 4965 Abu Dawu hadith no. 4924 and 4926) (Kurdian, 2017). This contradiction is even brought to the realm of fiqh or Islamic law, whether arts is haram, mubah, or makrooh (Suhendra, 2017). However, Islamic law controversy on arts seems inconsistent when dealing with increasingly complex artistic realities. The public believes that dangdut (Indonesian folk and traditional popular music) is haram because it is expressed erotically and sexy movements, rather than dangdut with religious lyrics of Roma Irama that full of wisdom (Huriyudin, 2014). Included in this case is Selawatan (reading du'a together accompanied by music) which is staged in the performing arts (Andre Indrawan, 2010), even later emerged musical groups campur ngaji, Which is the combination of pengajian (learning Islam) and campursari (an Indonesian music genre) (Sunarto, 2013). The phenomenon of arts and religion controversy in Indonesia reached its peak when Muhammad Yaser was invited by the Minister of Religious Affair of Republic of Indonesia, Lukman Hakim Saifuddin, to present the Tilawah Langgam Jawa (chanting the Quran with Javanese style music) in the Memorial of Isra Mi'raj of Prophet Muhammad Saw at the State Palace of the Republic of Indonesia. After chanting the holy verses of the Quran with the Javanese style, Yaser reaps blasphemy, verbal abuse in social media (Yaser, 2016).

In the context of education, arts have always been marginalized by science (David A. Sousa, 2012). The development of science laboratories takes precedence over performing arts performances (Suyadi, 2016). The learning of arts only becomes an optional extracurricular activity that is not a must, whereas science becomes the required curricular activities (Suyadi, 2016). Low scores on arts learning have no effect on graduation, whereas low scores on science learning can result in failure in schooling (Suyadi, 2016).

Behind all the controversies of arts, Islam, and science above, there is a unique phenomenon in the institution of Early Childhood Education, which is the occurrence of synergy between arts, Islam, and science in learning (Suyadi, 2016). In other words, the synergy between arts, science, and Islam only occurs in the world of children, especially Early Childhood Education, which is in the form of Day Care, Kindergarten, Raudatul Athfal (Islamic Kindergarten), and Bustanul Athfal (Islamic Kindergarten) (Suyadi dan Maulidya Ulfa, 2013). In fact, according to Siti Zaenab, 
early childhood teachers are not enough to only meet the academic qualifications of Bachelor degree on Early Childhood Education, but also must have the competence of singing and dancing (Zaenab, 2016). Thus, the children are free to sing and dance, either singing Islamic songs or other religious music. Uniquely, the movement, dance, and singing of children are often educative (Kusumastuti, 2004) and even at the same time oriented to the development of science. Moreover, all science and religious learning activities are conditioned by the content of arts. For example, early literacy through singing techniques (Inten, Dinar Nur, 2016), learning mathematics with songs and music (Song An, Mary Margaret Capraro, 2013), introduction of the hija'iyah letters (Arabic letters) packed with motion and song (Ali \& Bernyanyi, 2015), memorizing the Quran verses with audio music (Putra, Gumilar, Kusuma, Purnomo, \& Basumerda, 2018) and so on. Arts has become a basic need in early childhood learning.

However, the higher the education level, the more art is reduced. At the level of primary education, the proportion of learning arts began to be reduced. In the junior high school level, arts education is very little. In the high school level, arts began to disappear, and In the higher education level, arts education is longer found (Suyadi, 2016), except for the art department itself, although some parents disagree when their children go for arts courses because the career is less than brilliant.

Research on science and religion has been done, but not yet found that gives a touch on arts. Some of the studies that may be mentioned here are; Islamization of science initiated by Ismail Raji Al-Faruki (Al-Faruqi, 1995); Islamic scholarship initiated by Kuntowijoyo (Kuntowijoyo, 2004), and the integrationinterconnection initiated by Amin Abdullah (Abdullah, 2015). However, all three have not given a touch on arts between science and religion, including Al-Faruki who discussed arts separately from Islamization of science (Umma Farida, 2014). Other recent studies are still questioning the scientific and religious struggles such as that of Edwar Said (Syarif, 2013) or merely reinforcing the notion of integrationinterconnection by interpreting science verses in the Quran as done by Agus Purwanto (Purwanto, n.d.) and Purwaningrum (Purwaningrum, 2015).

This research describes the synergy between arts, science, and religion in early childhood learning, especially in the perspective of neuroscience. The application of neuroscience perspective is necessary because according to George S. Morrison, current neuroscience has always been a reference to early childhood learning practices (George S. Morrison, 2012). The theory of neuroscience used as a knife of analysis is neuroscience in Eric Jensen's point views, in which arts have neurobiology base on the brain (Eric Jensen, 2010). Thus, this research is important to do, because this is to foster the soul arts in children that will color their life character, filled with joy, excitement, and beauty. Without arts, children cannot develop holistically, and also will experience the risk of aesthetic expression disruption, can even have a long-term impact such as experiencing split personality.

\section{Method}

This research was conducted throughout 2017 at three Early Childhood Education institutions, which were Kindergarten of Aisyiyah Bustanul Athfal (ABA) Nitikan Yogyakarta, Raudatul Athfal (RA) Masyitoh Wonosari Gunung Kidul, and 1 Sleman Kindergarten Yogyakarta. Selection of the three kindergartens was because it has a different learning style of science and Islamic religion. 
ABA Nitikkan kindergarten Yogyakarta patterned by Muhammadiyah, RA Masyitoh Wonosari patterned by Nahdlatul Ulama and 1 Sleman Kindergarten patterned by both Muhammadiyah and Nahdlatul Ulama.

This research used a qualitative approach. Data collecting techniques were done by observation, interview, and documentation. Observation focused on science learning through arts as Jensen disclosed, movement art, visual arts, and musical arts. More interviews were conducted for early childhood teachers, some students, and parents. Documentation focused on students' performance in science learning with a touch of arts and religion. Data analysis was done in descriptive, comparative, and interpretative. The results of observation and documentation, clarified by interviews, both to teachers and children, and then interpreted on the basis of neuroscience learning theories.

\section{Findings and Discussion}

The research results of arts learning practices at three Early Childhood Education institutions in Yogyakarta were analyzed using neuroscience and art theories as proposed by Jensen and Sousa. Sousa divided arts into four, musical arts, visual movement, and literature; while Jensen divided arts into three types, musical arts, and visual movement. This research uses both, except literature, with a consideration that in early childhood education institutions is very minimal in literature learning.

\section{Arts in early childhood learning}

Sousa stated that learning involves different brain tissue. Visual arts (painting, drawing, and coloring) is processed in the occipital lobe and the temporal lobe; literature arts (singing, prose, poetry, and the like) is processed in the broca and wernicke areas; movement arts (dance, gymnastics, and the like) is processed in the motor cortex, especially the thin band that crosses the upper part of the brain; musical arts is processed in the auditory cortex, particularly the temporal lobe (David A. Sousa, 2012). Pay attention to figure 1 !

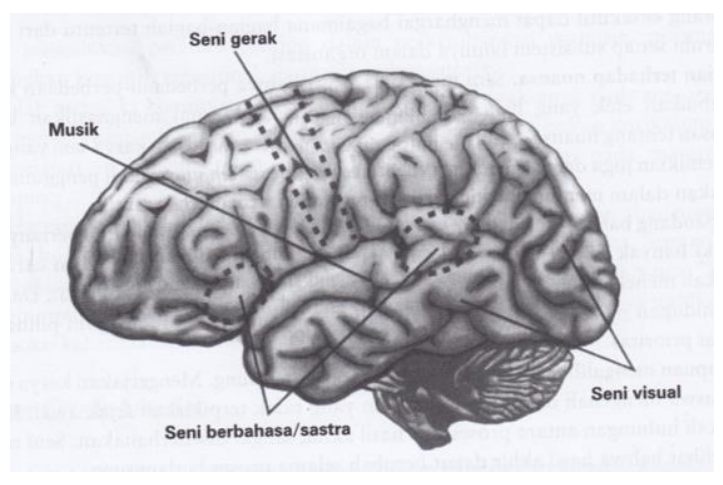

Figure1. Arts activates different areas of the brain

(David A. Sousa, 2012)

Using electroencephalography techniques, neuroscientists have found that arts training require one to focus attention so that arts activity has implications for cognitive enhancement. That is, when children learn arts from an early age, their cognitive development is more optimal. In addition, arts always involve strong emotions that have implications for improving students' memory. This indicates that arts and science are fundamentally synergistic. Thus, the practice of learning that contradicts arts and science is wrong. In the world of science, arts interact with science and become an inseparable part. For example, NASA employs artists to design satellite display data for easy understanding of operators; biochemists use the form of folds of yarn on knitted clothes as a way of explaining the folds of chemical proteins; computer experts encode messages on a certain frequency of music to avoid interception or blockade of electrical messages; Genetic scientists convert complex data into musical notation to facilitate data analysis (Pasiak, 2009).

Jensen, through experimental research of brain-imaging technology, found out that arts have the most basic structure of any brain 
function, even (Eric Jensen, 2010) stated that arts have a neurobiological basis in the human brain (Eric Jensen, 2010). Jensen divided arts into three based on the neurobiological basis. Figure 2 explains the three types of arts in the human brain.

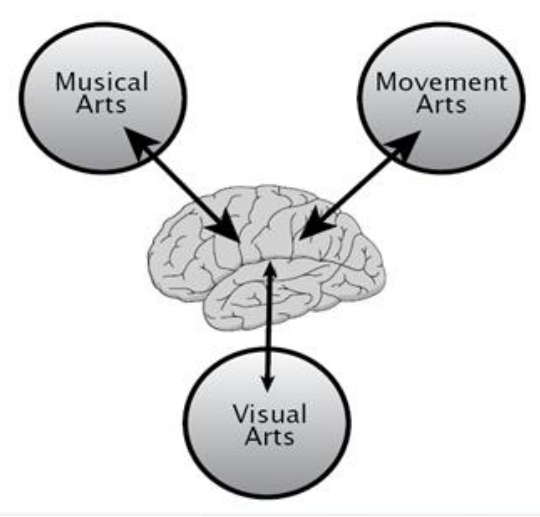

Figure 2. The basis of arts neurobiology in the brain, musical arts, movement arts, and visual arts of Eric Jensen (Eric Jensen, 2010)

First are musical arts. Musical arts means making music, listening to music, singing, rapping, composing music, reading music (musical scale), analyzing music, organizing, noting, creating music, and producing music (Eric Jensen, 2010). Musical arts can improve human survival, such as: improving the cognition system, including visual-spatial, mathematics (counting interval), and creativity; enhance the positive emotional system, such as social, personal, cultural appreciation, and aesthetics; improving perceptual systems, such as listening (melodic contour), vision, and other senses; improving memory system through increased concentration and recall.

The musical arts in various Early Childhood Education institutions as shown in figures $1 \mathrm{a}, \mathrm{b}$, c, d above is showed that the percussion and drum bands cannot be followed by all children. This is not because this type of art is only an optional program as in the education level above it, but because of limited facilities and infrastructure. Nevertheless, children are occasionally trained to play these types of musical instruments, while a group of other special children is given stronger treatments to master this musical instrument better. A group of children who are trained to play a special musical instrument is who will be performed when the school institutions have important events, such as commemorations of national holidays, such as Kartini day, national education day, independence anniversary, even religious holidays, such as Nuzulul Qur'an, Isra 'Mi'raj, Maulid' of Prophet Muhammad SAW, and so on. In fact, these arts activities are often considered as superior activities that can easily increase popularity and trust among the community. Arts skills are also often the top activities in various events in the institutions, such as akhirussanah (graduation or academic year-end activity). These activities are always full of arts performances with various expressions.

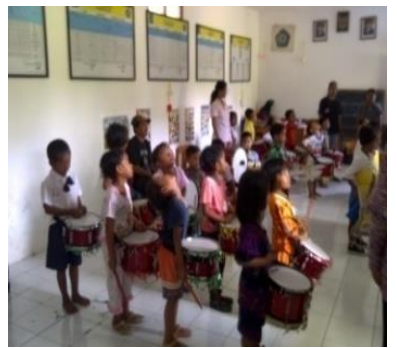

Figure 3a. An activity of drum band musical art training in Ngudi Wasis Kindergarten Yogyakarta

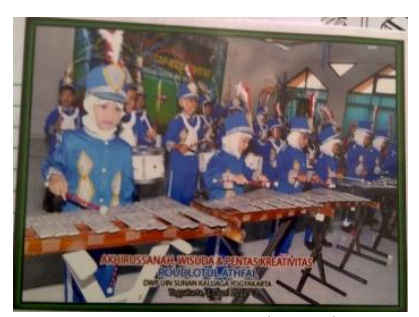

Figure $3 c$. Drum band performance

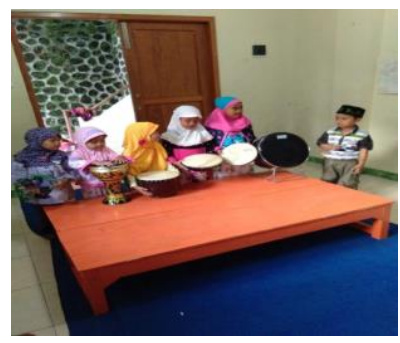

Figure 3b. Islamic Art (Rabana) in Gayamharjo Kidergarten, Sleman Yogyakarta

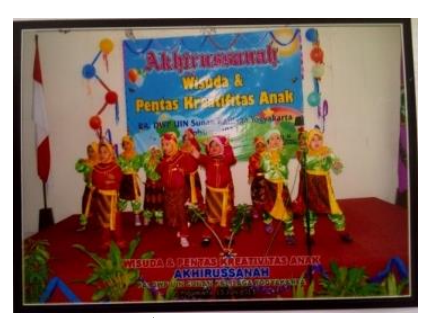

Figure 3d. Arts as creativity performances
Second is visual arts. Visual arts include design, paper and canvas works, photography, drawing, illustration, painting, and production arts. Included in this are technical arts in theater or drama, such as: costume design, make-up, lighting, props, and scenery (Eric Jensen, 2010). 
Broadly, the visual arts also include making of film, stories, video, visualization, shooting, editing, and computer-based graphic design. Technically, visual arts include architectural techniques, visual thinking, graphic organizers, mind maps, multimedia usage, website development, and exploratory (Eric Jensen, 2010).

Arts in early childhood education are dominated by drawing, coloring, and painting. Although Patriani stated that the classical literature of Islamic arts only recognizes the calligraphy and ornamentation of Arab and Middle East (Patriani, 2017), but in the context of early childhood learning in Indonesia, especially the three Early Childhood Education institutions that are the subject of this research put calligraphy as an optional activity.

In contrast to percussion music that only became extracurricular activities, drawing, coloring, and painting are the core activities of learning. These activities are often staged in the various arena of children's creativity. Figure $4 \mathrm{a}$ and $4 \mathrm{~b}$ below are drawing and coloring lessons at RA UIN Sunan Kalijaga Yogyakarta.

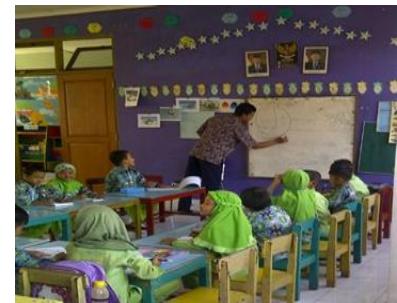

Figure. 4a.Drawing and coloring activities in early childhood learning at RA UIN Sunan Kalijaga

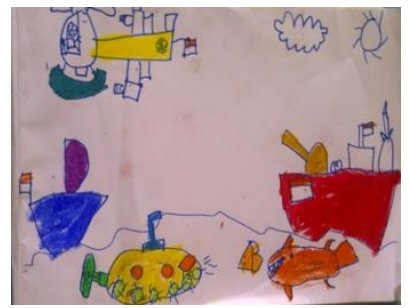

Figure. 4b. Results of student's drawing and coloring activities in early childhood learning at RA UIN Sunan Kalijaga
Figure $4 \mathrm{a}$ above explained that a teacher teaches on how to draw aircraft to children at RA UIN Sunan Kalijaga. The teacher only gives examples of aircraft drawing techniques that are easy and simple so easy to imitate by the children. The picture of picture $4 \mathrm{~b}$ is the picture of one of the student's works in that class. The picture has been colored so that it is more interesting than the teacher's example. In fact, the elements in the child's drawing are more complex than the picture of teacher's. In an interview with the child who drew $2 \mathrm{~b}$, he said that the plane that was drawn was a fighter, while inside it was a submarine for war and a missile Tank. When being asked why draw so? It turns out that the child playing war with the play station every day. Therefore, through drawing activities, the child can express his life experience and imagination

Third is the movement arts. The movement arts has many kinds, such as dramatic (dance, drama, pantomime, theatre, musical), industry (sculpture, paint, design, construction, architecture, metal or wood), recreation (outbond, class games, physical education, and active health program). The kinaesthetic arts provides a significant vehicle for improving learning through critical neurobiological systems, including cognition, emotion, immunity, circulation, and perceptual motor (Eric Jensen, 2010). Jensen explained that movement affects the brain in many ways and most of the brain is more active during physical movements.

Movement arts in early childhood learning is more dominated by the motion and songs as well as children's health gymnastics. In general, movement arts in early childhood can be divided into three. First is the movement arts being done every day as an activity or introduction to entering the core activities. Second is the movement arts in the form of dance, such as traditional dance, modern dance, and dance created by the teachers. Dance in early childhood learning is separated into core activities and extracurricular. Usually, this activity is done once a week that later will be staged in certain moments. Third is the movement arts in the form of children's health gymnastics. This 
activity is usually done once a week. In gymnastics, it is always accompanied by music and children's songs to spur the spirit. Especially for gymnastics, usually always accompanied by audio music and performed once a week. Various activities of this art can be seen in the figure $5 \mathrm{a}, \mathrm{b}$, and $\mathrm{c}$ as follows.

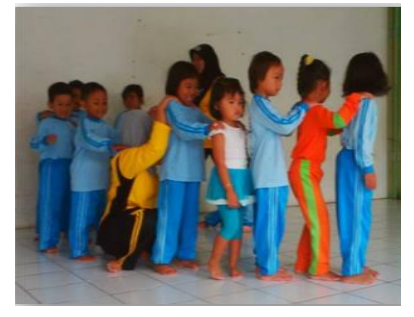

Figure 5a. Movement art of learning opener

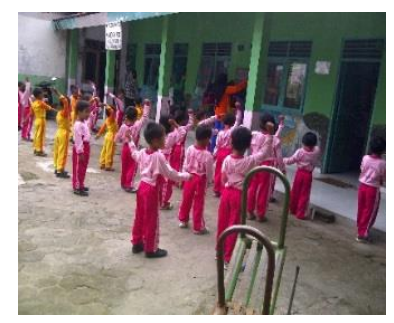

Figure 5b. Movement art of children's gymnastics

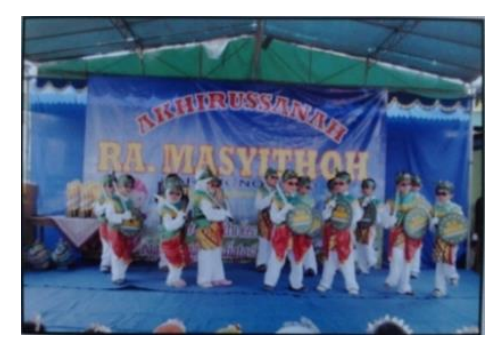

Figure 5c. Academic year-end festival with children dance performance

Figure 5a-b-c above shows the learning of movement arts, especially dance expressed by simple movements, such as spinning, moving to the right and left or forward and backward. Arts content is more emphasized on Islamic values, such as hadrah and selawatan as stated by Indrawan (Andre Indrawan, Susanti Andari, 2009). The movement arts in early childhood learning greatly avoid erotic movements as expressed by less ethical dancers as criticized by Oemar Yahya and Huriyudin (Huriyudin, 2014).

\section{The spiritual dimension in arts learning}

I Made Marthana Yusa (referred to as Yusa) defined arts as a human spiritual activity that reflects the work reality, which because of its form and content has the data to evoke certain experiences in the spiritual realm of the recipient (I Made Marthana Yusa, 2016). Yusa also stated that arts come from the Sanskrit, 'sani' which means worship, offerings, and a religious ceremony. Thus it can be understood that arts are essentially a spiritual aesthetic expression to get closer to God, so the artist is religious people.

In Islam, arts as a spiritual expression can be seen in the Sufi dance Jalaluddin Rumi, the circling movement accompanied by drums and flutes. As Murdiati put it, that Rumi and his legendary spiritual dance became an extraordinary work of Islamic spiritual art to approach the Creator (Eni Murdiati, 2011). Hajriansyah also pointed out that Rumi climbs the divine summit through literary art in the form of poems taking the mystical nuance but still Islamic (Hajriansyah, 2015). Nuraini and Ernita Dewi also said that the Sufis are committed to God through artistic expression. Al-Hallaj and Rabiah al-Adawiyah brought their lives closer to God and explained the beauty of ma'rifah (mystical intuitive knowledge of spiritual truth reached through ecstatic experiences, rather than revealed or rationally acquired) through poetry. Likewise Jalaludin Rumi, who enjoys the existence of God through religious dance (Manan, 2012)(Manan, 2012).

Historically, the arts of Islam has evolved since the establishment of the Ka'bah by the prophet Adam, which then restored by the prophets Ibrahim and Isma'il, then refined by Prophet Muhammad thus growing calligraphy art, orchestra, qasidah (Arabic poem of mourning or praise), and so on (Fikriarini, 2010). Literary arts is also growing rapidly even writers said that Quran as the largest literature book in the world (Huriyudin, 2014). Al-Faruki as stated by Farida also stated that the aesthetic expression of tawheed (oneness of God) embodies in various forms of arts, such as calligraphy, ornamentation, musical arts, 
literature, and space arts (Umma Farida, 2014). Thus, historically and philosophically arts do not contradict Islam.

In its development, Islamic arts with its various expressions not only become a media to be closer to God but also become a media of da'wah (preaching of Islam) as well as entertainment or performing arts (Andre Indrawan, 2010). Hasbi Indra mentioned that the Wali (revered saints of Islam in Indonesia) use arts as a medium of da'wah. In pesantren (boarding house to study Islam) in general, including salaf pesantren, Shalawat art has entered the curriculum as a defense medium in the era of globalization (Indra, 2017). In Pondok Pesantren Krapyak, also developed women Shalawat hadrah (Andre Indrawan, Susanti Andari, 2009). More than that Aini found the phenomenon of living hadith about Shalawat in various communities or assemblies in Yogyakarta (Aini, 2014). Although I Gede Arya Sucitra said that the phenomenon as a syncretism of arts and Islam, (Sucitra, 2015) but the phenomenon continues to grow and develop in the midst of modern society. Thus, long before Al-Faruki wrote about the art of monotheism, historically the artists were originally a spiritual people or even a religious people. Aesthetic expressions can thrill the soul of the doer so that arts is not only a dry meaning aesthetic but rather a high spiritual dimension.

Bambang Soenarto explained that the artistic contradictions in Islam have actually been explained by Yahya Oemar since 1983. Yahya Oemar collected 13 postulates that allow arts and 10 postulates that prohibit arts. The arguments were analyzed comparatively so that it can be concluded that the law of arts is sunnah when bringing benefits and makrooh (detestable/abominable) when bringing madharat (bad thing) (Sunarto, 2013). Furthermore, Yahya Oemar said that what makes arts haram is not in essence, but on other things on how the artists expressed it. However, other recent studies seem to be unsatisfied with Yahya Oemar's explanation, so that artistic contradictions in Islam are still being discussed. Therefore, opposing arts and Islam in excess is less effective.

In the context of early childhood education, the synergy of arts and Islam is applied in various learning. Given the controversies of arts and Islam, some Early Childhood Education institutions that are strongly affiliated with Islam such as Aisyiyah Bustanul Athfal Kindergarten with Muhammadiyah ideology and Raudlatul Athfal which the majority have Nahdlatul Ulama (NU) ideology are relatively careful in using arts in order to the arts being taught does not conflict with Islam. But for Early Childhood Education institutions in general, such as Public Kindergarten, relatively free in arts learning.

From the side of religiosity, arts in early childhood learning are expressed in various ways. In terms of musical arts, it is more likely to teach classical music, such as rabbana and percussion (see figure $3 \mathrm{a}, \mathrm{b}, \mathrm{c}$, and $\mathrm{d}$ ), not piano music or rock or even dangdut music. When performing musical arts, children wear Muslim dress that covers all of their aurat (private parts according to Islam). In terms of the movement arts, children do not at all issue to an erotic expression, unlike what is feared by Muslim artists who still think arts is haram (Suhendra, 2017).

In the case of visual arts, early childhood learning tend to make man-made objects as objects of learning, such as aircraft, cars, homes, and so forth. It is intended to avoid some hadith that prohibit painting sentient beings for fear that in the Hereafter will be held accountable. Figure $4 \mathrm{a}-\mathrm{b}$ shows that learning using the plane as the object. This is because some personnel of RA UIN Sunan Kalijaga is still worried that if they teach to draw living creatures is in opposition to Islamic syari'at (law), especially the 
hadith that prohibit the painting of living creatures (Suhendra, 2017).

In the case of movement arts in early childhood learning, it tends to express simple movements, such as spinning, shifting to the left, forward and backward, as well as avoiding erotic movements such as those expressed by some erotic artists on stages (see figure $5 \mathrm{c}$ ). This is intended to avoid "other things" that make arts haram as Oemar yahya stated (Sunarto, 2013).

Based on the three types of arts in early childhood learning it can be concluded that the spiritual dimension in arts continues to thrive among Muslim children, but is still overshadowed by fears and worries of some views that forbid arts. Early Childhood Education institutions basically do not embrace one view in full; arts may be taught as what stated by Rumi and Alfaruki, but it also does not totally reject that the arts can be makrooh.

Religious Creativity: the synergy of arts, science, and Islam

In the perspective of creativity, the definition of arts as proposed by Yusa needs to be considered again. In addition to arts related to the spiritual dimension as stated above, Yusa also stated that the word 'seni' in Indonesian has a synonym of meaning with the word 'art' in English. The origin of the word 'art' is derived from the word 'ars' which means 'technique' or dexterity, proficiency in the work of something or extraordinary abilities brought on from birth. (I Made Marthana Yusa, 2016). That is, arts basically have a strong relationship with science. Primordial societies that do not yet have science rely solely on the arts to defend life and transmit their noble values to the next generation. Thus the arts in primordial society are the science itself.

Neuroscientists also said that arts become the most creative educational stimulation. This is because the arts are able to activate more areas in the brain than non-art stimuli. The more active areas in brain are the greater the potential for creative thinking. Moreover, the brain areas originally responsible for cognition and emotion are also actively involved in the processing of creative stimulation. Therefore, arts in the early childhood learning of children can activate the more complexes parts of the brain so potentially trigger creative ideas.

Engaging in arts activities can enhance spontaneity and self-expression, control the restrictive effects of inhibition, and produce creative and productive works (Nuraida, 2017). Arts can also develop the attention control needed for toughness in the face of fear, frustration, and failure that is usually present when trying to create true monumental ultimate works.

Artistic activities also enhance the skills of estimation and imagination and the ability to introspect because artistic activities often require artists to create their works and to evaluate the performance quality of other artists. Thus, arts learning is not only for aspiring artists, however, it is also not only because to enhance academic cognitive abilities, but rather to be imbued by cultural awareness and the quality of long-term learning, not an instant result.

David A. Sousa said that the life of a nation will not be empty of the arts and cultures which are contained knowledge. Arts has a major contribution to the development of the nation's thinking, even the arts is the peak of thought and culture of a nation. Furthermore, Sousa also stated that we will never find the life of a nation, past and present, which have no culture, art, and dance. However, from the past until now, there is still the life of a nation that does not know reading and writing (David A. Sousa, 2012). This shows that the life of a nation will not survive without arts and culture. Conversely, a nation will not survive despite having the ability 
to read and write. Thus, arts and culture become a primordial science for a nation that has not known literacy to transmit cultural values to the next generation so as to survive intelligently. Referring to the artists Yusa, and neuroscientist Sousa above, it can be concluded that contradicting arts and science is a big mistake. Therefore, education must be able to synergize between arts and science in learning.

The research data shown in Figure 3a-b-c, $4 a-b$ \& 5a-b-c explained how the three types of arts as proposed by Jensen and Sousa are synergized constructively in children's learning, in which more involving students in learning (Lia Kurniawati, Abdul Muin, 2015). When Yusa stated that arts are related to special skills, it is clear that children need special skills in playing one type of musical instrument, percussion for example (see figure 3c). Every musical instrument needs a certain technique to play it according to the rhythm so that children indirectly learn the rhythm of high-level social skills.

When Sousa said that arts become the science of primordial society as a medium for transmitting the values that they believe, then Early Childhood Education make arts as a medium for the development of Islamic character education values, such as hadrah and selawat (Andre Indrawan, Susanti Andari, 2009). This can be seen on the performances of academic year-end or akhirusanah at RA UIN Sunan Kalijaga. Children perform Islamic arts with Shalawat's lyrics to the Prophet with a melodious voice and calm music (Andre Indrawan, 2010).

Referring to the statement of Sousa and Jensen who said that arts have a neurobiology basis on the brain, and even more arts activities will activate certain areas of the brain that potentially bring up creative ideas, then Islamic arts in early childhood learning is an educative stimulation that has potential for development of children's creativity.

\section{Conclusion}

Based on the results of the research and discussion above, it can be concluded that in early childhood learning of the three Early Childhood Education institutions in Yogyakarta with various Islamic features, they are manifested in three types of arts, which are musical arts (drum band, percussion and rabbana), movement arts (gymnastics and dancing) as well as visual arts (drawing and coloring objects of made by human.

The synergy of arts, science, and Islam in early childhood learning contains the spiritual dimension as Jalaluddin Rumi and Al-Faruki put forward. Arts is not merely a monotheistic and prophetic expression as al-Faruki discusses, but becomes a medium to get closer to God as the dance of Sufi Jalaluddin Rumi. Salawat art performance, for example, is one of the manifestations of dance arts with more modern creations.

Synergy of arts, science and Islam in early childhood learning is also the most complex educational stimulation that is able to activate more areas of the brain, thus give the potential to create creative religious ideas.

\section{References}

Abdullah, M. A. (2015). Religion, Science, and Culture: An Integrated, Interconnected Paradigm of Science. Al-Jami'ah: Journal of Islamic Studies, 52(1), 175. https://doi.org/10.14421/ajis.2014.521.17 5-203

Aini, A. F. (2014). Living Hadis dalam Tradisi Malam Kamis Majelis Shalawat Diba' BilMustofa. Ar-Raniri: International Journal of Islamic Studies, 2(1), 221-235. 
Ali, M., Bernyanyi, M. (2015). Peningkatan pengenalan huruf hijaiyah melalui metode bernyanyi pada anak usia 5-6 tahun.

Farida, U. (2014). Pemikiran Ismail Raji AlFaruqi Tentang Tauhid, Sains dan Seni. Fikrah, 2(2), 207-227.

Faruqi, I. R. (1995). Islamisasi Pengetahuan. (terj. Anas M., Ed.). Bandung: Pustaka.

Fikriarini, A. (2010). ARSITEKTUR ISLAM: Seni Ruang dalam Peradaban Islam. ElHarakah, 12(3), 194-206.

George S. Morrison. (2012). Dasar-dasar Pendidikan Anak Usia Dini (PAUD). Jakarta: Indeks.

Hajriansyah. (2015). Pengalaman Beragama Sufi Jalaluddin Rumi dalam Perspektif Psikologi. Ilmu Ushuluddin, 14(1), 4958.

Hebb, D. O.. (2012). Teori Neurofisiologis Dominan. In B.R. Hergenhahn dan Matthew H. Olson (Ed.), Theories of Learning, Trj. Triwibowo B.S., Edisi Ketujuh, Cetakan IV. Jakarta: Kencana.

Huriyudin. (2014). Ekspresi Seni Budaya Islam di Tengah Kemajemukan Masyarakat Banten. Jurnal Lektur Keagamaan, 12(1), 257-296.

Indra, H. (2017). Salafiyah Curriculum At Islamic Boarding School in The Globalization Era. Tarbiya: Journal of Education in Muslim Society, 4(1), 7488.

Indrawan, A. (2010). Selawatan Sebagai Seni Pertunjukan Musikal. Resital, 11(2), 95105.

Indrawan, A. Susanti A. S. (2009). Seni Musik Hadrah Putri di pondok Pesantren Al Munawwir Krapyak. Resital, 10(1), 1-9.
Inten, D. N., dkk. (2016). Literasi dini melalui teknik bernyanyi. Al Murabbi, 3(2013), 70-91.

Jensen, E. (2010). Art With the Brain in Mind. Alexandria,Virginia USA: Association for Supervision and Curriculum Development. Retrieved from http://www.ascd.org/publications/books/1 01011.aspx

Kuntowijoyo. (2004). Islam sebagai Ilmu: Epistemologi, Metodologi dan Etika. Yogyakarta: Teraju.

Kurdian, N. K. bin. (2017). Studi Komparasi Antara Metode MTA (Majelis Tafsir AlQur'an) dalam Menyikapi Kontradiksi Hadits Tentang Musik dengan Metode Ulama Syafi'iyah. Al-Majaalis, Jurnal Dirosah Islamiyah, 5(1), 81-114.

Kurniawati, Lia., Abdul Muin, R. M. (2015). Constructivism Based Learning: Design and Practice. Tarbiya: Journal of Education in Muslim Society, 2(2), 123130.

Kusumastuti, E. (2004). Pendidikan seni tari pada anak usia dini di taman kanak-kanak tadika puri cabang erlangga semarang sebagai proses alih budaya. Harmonia Jurnal Pengetahuan Dan Pemikiran Seni, $V(1), \quad 1-16$. https://doi.org/10.15294/harmonia.v5i1.8 26

Manan, N. A. (2012). Seni Ala Sufi Dalam Pendekatan Diri Kepada Tuhan Dan Implikasinya Dalam Psikoterapi Islam. Jurnal Substantia, 14(2), 251-262.

Mawardi, K. (2013). Seni sebagai ekspresi profetik. Ibda' Jurnal Kebudayaan Islam, 11(2), 131-147.

Murdiati, E. (2011). Tarian spiritual jalaluddin rumi. Wardah, XXII(22), 9-17. 
Nuraida. (2017). The Effect of Creativity Teaching Tecnique to Creative ProblemSolving Ability in Studies. Tarbiya: Journal of Education in Muslim Society, 4(1), 53-62.

Pasiak, T. (2008). Revolusi IQ/EQ/SQ: Menyingkap Rahasia Kecerdasan Berdasarkan Al-Quran dan Neurosains Mutakhir. Bandung: Mizan Bandung. Retrieved from http:/www.bukukita.com/Agama/Islam/5 7846-Revolusi-IQ-EQ-SQ-:-MenyingkapRahasia-Kecerdasan-Berdasarkan-AlQuran-dan-Neurosains-Mutakhir

Pasiak, T. (2009). Unlimited Potency of the Brain: Kenali dan Manfaatkan Sepenuhnya Potensi Otak Anda yang Tak Terbatas. Bandung: Mizan Bandung. Retrieved from http://mizan.com/index.php?fuseaction=b uku_full\&id=2629

Pasiak, T. (2016). Tuhan Dalam Otak Manusia : Mewujudkan Kesehatan Spiritual Berdasarkan Neurosains. Mizan, Bandung.

Patriani, S. R. (2017). Pengaruh Sosiokultur Budaya Islam Terhadap Seni Lukis Kaligrafi Di Indonesia. Jurnal Buana Pendidikan, 13(23), 77-89.

Purwaningrum, S. (2015). Elaborasi Ayat-Ayat Sains dalam Al-Quran: Langkah Menuju Integrasi Agama dan Sains dalam Pendidikan. Inovatif: Jurnal Penelitian Pendidikan, Agama, Dan Kebudayaan, 1(1), 124-142.

Purwanto, A. (n.d.). Nalar Ayat-Ayat Semesta.

Putra, P. S., Gumilar, R., Kusuma, S. R., Purnomo, H., \& Basumerda, C. (2018). The effect of Quran m urottal's audio on short term memory. Matec Web of Conferences 154, 01060, 2-5.
Song An, Mary Margaret Capraro, D. A. T. (2013). Elementary Teachers Integrate Music Activities into Regular Mathematics Lessons: Effects on Students' Mathematical Abilities. Berkeley Planning Journal, 26(1), 217-220. https://doi.org/10.5811/westjem.2011.5.6 700

Sousa, D. A. (2012). Bagaimana Otak Belajar Edisi Keempat. Jakarta: Indeks. Retrieved from http://www.indekspenerbit.com $/$ index.php? route $=$ product $/ \mathrm{pr}$ oduct\&product_id=444

Sucitra, I. G. A. (2015). Transformasi Sinkretisma Indonesia dan Karya Seni Islam. Journal of Urban Society's Art, 2(2), 89-103.

Suhendra, D. (2017). Perspektif Hukum Islam tentang Seni. Asy-Syar'iyyah: Jurnal Ilmu Syariah Dan Perbankan Islam, 2(1), 4759.

Sunarto, B. (2013). Konsepsi Filosofis di Balik Musik Sholawat Campurngaji. Jurnal Seni \& Budaya Panggung, 23(2), 117-135.

Suyadi dan Maulidya Ulfa. (2013). Konsep Dasar PAUD. Bandung: Remaja Rosdakarya. Retrieved from https://www.tokopedia.com/bukukita/kon sep-dasar-paud-oleh-suyadi-dan-maulidya

Suyadi. (2016). Teori Pembelajaran Anak usia Dini Dalam Kajian Neurosains. Bandung: Rosda Karya.

Syarif, E. (2013). Pergulatan Sains dan Agama. Refleksi, 13, 629-642.

Yaser, M. (2016). Memperkenalkan Tilawah Langgam Jawa. Conference Proceedings ARICIS I, 1(1), 394-407. 
Yusa. I Made M. (2016). Sinergi Sains, Zaenab, S. (2016). Human Resource Teknologi Dan Seni Dalam Proses Management For Early Chilhood Berkarya Kreatif Di Dunia Teknologi Informasi. education. Tarbiya: Journal of Education in Muslim Society, 3(2), 242-251. 